\title{
Seed Germination of Faidherbia albida (Delile) A. Chev as Influenced by Different Pretreatments
}

\author{
*11IROKO, OA; ${ }^{2}$ SOWUNMI, IL; ${ }^{1}$ AJEKIIGBE, JM; ${ }^{2}$ RUFIAI, SO; ${ }^{1}$ WAHAB, WT \\ ${ }^{* 1}$ Department of Sustainable Forest Management, Forestry Research Institute of Nigeria P.M.B 5054, Jericho Hill Ibadan, Oyo State, \\ Nigeria. \\ ${ }^{2}$ Biomedicinal Research Centre, Forestry Research Institute of Nigeria P.M.B 5054, Jericho Hill Ibadan, Oyo State, Nigeria. \\ *Corresponding author: olayinkairoko@gmail.com; Tel: 08033187525
}

\begin{abstract}
Faidherbia albida is an agroforesrty tree that has the potential of promoting agroforestry establishment in Nigeria. The seeds are glossy due to the presence of wax in the seed coat which prevents easy penetration of water. Thus, this study assessed the effect of different pretreatments (biological, mechanical and chemical) on the germination of $F$. albida seeds. The treatments include; seeds scarified at the helium, soaked in cold water for 24 hours, soaked in hot water for 3 minutes, 5 minutes, 10 minutes, \& 15 minutes and soaked in Conc. $\mathrm{H}_{2} \mathrm{SO}_{4}$ for 3 minutes, 5 minutes, 10 minutes, and 15 minutes. The result showed that all treatment had uniform germination percentage of $100 \%$ but seeds soaked in $\mathrm{H}_{2} \mathrm{SO}_{4}$ for $15 \mathrm{~min}$ and $10 \mathrm{~min}$ had the highest germination value of (65.25) and (65.00) respectively, followed by $15 \mathrm{mins}$ soaking in hot water (47.14) while the least germination value was recorded in seeds scarified mechanically (33.31). Analysis of variance revealed that there was no significant difference in the treatments. However, seeds treated with $\mathrm{H}_{2} \mathrm{SO}_{4}$ at 15 mins and $10 \mathrm{mins}$ had the best performance in terms of germination value compared with other treatments. Therefore, for optimum and uniform germination, the seed of $F$. albida seeds should be soak in concentrated $\mathrm{H}_{2} \mathrm{SO}_{4}$ for 15 min.
\end{abstract}

\section{DOI: https://dx.doi.org/10.4314/jasem.v25i7.28}

Copyright: Copyright $(2021$ Ikoko et al. This is an open access article distributed under the Creative Commons Attribution License (CCL), which permits unrestricted use, distribution, and reproduction in any medium, provided the original work is properly cited.

Dates: Received: 10 May 2021; Revised: 28 June 2021; Accepted: 01 July 2021

Keywords: Pre-treatment, germination value, seed quality, Faidherbia albida and peak value

Faidherbia is a genus of leguminous plants containing one species, Faidherbia albida, which was formerly widely included in the genus Acacia as Acacia albida. The species is native to Africa and it's commonly called apple-ring acacia because their circular seed pods resemble apple rings. (Ismail et al., 2016; Maab Osman et al., 2019). For a long time, this species was formerly called Acacia albida. It is a thorny tree growing up $6-30 \mathrm{~m}(20-98 \mathrm{ft})$ tall and $2 \mathrm{~m}(6.6 \mathrm{ft})$ in trunk diameter. It's highly resistant to drought due to deep-penetrating tap root. The bark is grey and fissured when old. According to Armstrong (2015), F . albida is found along flood plains of some areas in South Africa. F.albida flowers provide bee forage at the close of the rainy season showing it's important for raising bees, the seed pods are used for feeding livestock in Nigeria, and eaten by stock and game in Southern Africa (Bramm, 1997). The leaves are eaten by elephant, antelope, buffalo, baboons and various browsers and grazers, though strangely ignored by warthog and zebra (Kevin, 1990). The wood is used for canoes, mortars and pestles, and the bark is pounded in Nigeria and used as a packing material. Ashes of the wood are used as tanning agent for hides and as a depilatory and used in making soap. The wood is used for carving, the thorny branches is useful for a natural barbed fence. Some $90 \%$ of Senegalese farmers interviewed by Felker (1981) collected stored and rationed Acacia albida pods to livestock. It is valued in agroforestry as it fixes nitrogen, and a high yield has been achieved in at least one test plot of maize crops grown amongst the trees at a density of 100 to 25 tree per hectare (Bayala et al., 2010). According to a 2018 article by the Guardian, monocultures of this species are popular in parts of Niger, where it is known as gao in Hausa, to use for intercropping (MacLean, 2018). It is also used for erosion control. Its value as an agroforestry tree cannot be overlooked as this species drops leaves during raining season which helps to add nutrient to the soil which invariably improves the growth and productivity of crops (Burrow et al., 2018; Becking, 2020). Extract from the bark of $F$. albida is used in traditional medicine in Southern Africa, and Niger (MacLean, 2018).

F. albida is hard seeded which produces seeds with tough and hard seed coat (Connor, 2009). This condition does not encourage even germination but rather results in erratic germination of seeds (AldereteChavez et al., 2011). In other to achieve rapid and synchronous germination the seeds of $F$. albida need 
to be subjected to some physical or chemical treatment enhancing early germination (Butola and Bedola, 2004; Islam et al., 2009). Studies by Connor (2008) and Asiedu et al. (2011) suggested the treatment of seeds with hot water and scarification with $97 \%$ sulphuric acid increases germination percentage of hard coated seeds. Several other pre-sowing treatments have been suggested to enhance germination in seeds with hard seed coats. These include gibberellic acid, potassium nitrate, succinic acid, $\mathrm{HCl}$, nitric acid, boric acid, acetic acid, ethanol, methanol, benzene, xylene, urea, benzyl adenine, among others (Alves et al., 2000; Ghadiri and Torshiz, 2000; Idu et al., 2007; Schmidt, 2000). It has been noted by Orwa et al. (2009) and Asiedu et al. (2011) that very little work has been done on the plant thus the need to conduct further study to determine the best pre-treatment method that will help to break dormancy and give higher germination. Hence, this experiment investigated the effects of some pre-sowing treatments on the germination of Faidherbia albida seeds.

\section{MATERIALS AND METHODS}

Experiment Site: The study was carried out at the Seed Section of the Department of Sustainable Forest Management (SFM), Forestry Research Institute of Nigeria (FRIN), Jericho Hill, Ibadan, Nigeria. FRIN is located on the longitude $07^{0} 23^{\prime} 18^{\prime \prime} \mathrm{N}$ to $07^{0} 23^{\prime} 43^{\prime \prime} \mathrm{N}$ and latitude $03^{0} 51^{\prime} 20^{\prime \prime E}$ to $03^{0} 51^{\prime} 43^{\prime \prime} \mathrm{E}$ (Bolanle-Ojo et al., 2018). The climate of the study area is the West African monsoon with dry and wet seasons. The dry season is usually from November through March and is characterized by dry cold wind of harmattan. The wet season usually starts from April to October with occasional strong winds and thunderstorms. Mean annual rainfall is about $1548.9 \mathrm{~mm}$, falling within approximately 90 days. The mean maximum temperature is $31.9^{\circ} \mathrm{C}$, minimum $24.2^{\circ} \mathrm{C}$ while the mean daily relative humidity is about $71.9 \%$ (FRIN, 2017).

Seed Collection and Extraction: Matured fruits of $F$. albida were collected from Ogbomoso area of Oyo State and seeds were extracted from the pods. Washed and sterilized river sand was filled into germination trays $(30 \mathrm{~cm} \times 12 \mathrm{~cm})$ for germination investigation under mist propagator.

Experimental Design: This experiment was laid in a Completely Randomized Design (CRD). Ten (10) treatments were used for this experiment as shown in Table 1. Ten (10) seeds were used for each experimental units and replicated 5 times. A total of 500 seeds were used for this experiment.

Seed Pre-germination treatments and Methods: The experiment was subjected to 10 pre-germination treatments which comprises of mechanical scarification, cold and hot water (soaked for 3, 5, 10 and 15 minutes) and acid (soaked for 3, 5, 10 and 15 minutes). Mechanical scarification involved scarified at the helium (Table 1). All the treated seeds were sown in germination trays under a mist propagator.

\begin{tabular}{lll}
\multicolumn{2}{c}{ Table 1: Pre-germination treatments and methods } \\
\hline S/N & Treatment & Methodology \\
\hline T1 & Mechanical Scarification & Scarified at the helium \\
T2 & Cold Water $(24$ hours $)$ & Seeds soaked in cold water for 24 hours \\
T3 & Hot water $\left(60^{\circ} \mathrm{C}\right)$ & Seeds soaked in hot water for 3 minutes \\
T4 & Hot water $\left(60^{\circ} \mathrm{C}\right)$ & Seeds soaked in hot water for 5 minutes \\
T5 & Hot water $\left(60^{\circ} \mathrm{C}\right)$ & Seeds soaked in hot water for 10 minutes \\
T6 & Hot water $\left(60^{\circ} \mathrm{C}\right)$ & Seeds soaked in hot water for 15 minutes \\
T7 & Concentrated Acid & Seeds soaked in concentrated $\mathrm{H}_{2} \mathrm{SO}_{4}$ for 3 minutes \\
T8 & Concentrated Acid & Seeds soaked in concentrated $\mathrm{H}_{2} \mathrm{SO}_{4}$ for 5 minutes \\
T9 & Concentrated Acid & Seeds soaked in concentrated $\mathrm{H}_{2} \mathrm{SO}_{4}$ for 10 minutes \\
T10 & Concentrated Acid & Seeds soaked in concentrated $\mathrm{H}_{2} \mathrm{SO}_{4}$ for 15 minutes \\
\hline
\end{tabular}

Data Collection: The germinated seeds were monitored and data were collected on Germination assessment: The effects of pre-sowing treatment were assessed by daily counting of number of germinated seeds. A seed was considered to have germinated when the tip of the radicle emerged free of the seed coat (Auld et al., 1988). Daily germination percentage was summed up to obtain cumulative germination on each assessment. Germination period was determined as the number of days from first observed germination to when there was no more germination but energy period was arbitrarily defined in 12 days (Willan,
1993). Germination pattern was also determined by number of seeds that germinate at the different days after sowing (Viswanath et al., 2002). Germination energy is defined as the percentage by number of seeds in a given sample which germinate within a definite period such as 7-14 days under optimum or stated condition (Willan, 1987). Germination energy is also a measure of the speed of germination and hence, a measure of the vigour of seedlings (Willan, 1993). In addition, germination value which is a composite value that combines both germination speed and total germination was also determined. Germination value 
is an objective means of evaluating results of a germination test and is calculated using the formula proposed by Hartmann et al. (1997) as follows:

$$
G V=M D G \times P V
$$

Where: $\mathrm{GV}=$ Germination value; $\mathrm{MDG}=($ Final $)$ Mean daily germination; $\mathrm{PV}=$ Peak value mean daily germination

Germination Percentage (GP), Germination Energy (GE), Mean Daily Germination (MDG), Peak Value $(\mathrm{PV})$ and Germination value $(\mathrm{GV})$ were determined with the use of the following equations according to Schelin et al., (2003):

$$
\text { GP }(\%)=\frac{\text { total seeds germinated }}{\text { Total seeds sown }}
$$

Germination Energy (GE) is the percentage total of highest germination counts from the day it begins till when it starts diminishing divided by total seed sown.

$$
\mathrm{GE}=\frac{\ldots \ldots . x+y+z}{\text { Total sseds sown }} \times 100 \ldots \ldots(\text { Eqn. } 3)
$$

Where: $\mathrm{x}=$ the first highest germination count, $\mathrm{y}=$ higher germination count, $\mathrm{z}=$ high germination count

Mean Daily Germination percentage (MDG): This is cumulative total percentage of germinated seeds divided by exact germination day.

MDG $(\%)=$
$\frac{\text { Cumulative Total Percentage of seed sown }}{X}$ (Eqn. 4.$)$

Where: $\mathrm{x}=$ Exact germination day

Peak Value (PV) is the highest value calculated as MDG

Germination Value $(\mathrm{GV})$ is the product of the last day MDG and PV

$\mathrm{GV}=$ Last day $M D G X P V$ (Eqn. 5)

Total germination is expressed as Mean Daily Germination (MDG), calculated as the cumulative percentage of full seed germination at the end of the test divided by the number of days from sowing to the end of test period. Speed of germination was determined and expressed as peak Value, which is the maximum mean germination reached at any time during the period of the test (Willan, 1993).

Data Analysis Data collected were analyzed using descriptive statistics and Analysis of Variance (ANOVA) and results were presented in tables.

\section{RESULTS AND DISCUSSION}

The result revealed that the treatments had uniform $100 \%$ germination percentage. Seeds soaked in Conc. $\mathrm{H}_{2} \mathrm{SO}_{4}$ in 10 and 15 minutes had the highest peak value 17.33 and 17.40 respectively as well as germination value of 65.00 and 65.25 respectively followed by hot water treatment with peak value 12.57 and germination value (47.14) while the least value was recorded in mechanical scarification with peak value (9.33) and germination value (33.31) (Table 2). However, the ANOVA result revealed that there were no significant difference in all the treatments applied (Table 3).

Table 2: Comparison of Various Pre-treatment and germination value of $F$. albida seeds

\begin{tabular}{lllll}
\hline Treatment & $\begin{array}{l}\text { Germination } \\
\text { percentage } \\
(\%)\end{array}$ & $\begin{array}{l}\text { Peak } \\
\text { Value } \\
(\mathbf{P V})\end{array}$ & $\begin{array}{l}\text { Mean Daily } \\
\text { Germination } \\
\text { (MDG) }\end{array}$ & $\begin{array}{l}\text { Germination } \\
\text { Value }(\mathbf{G V})= \\
\text { PV X MDG }\end{array}$ \\
\hline T1 & 100 & 9.33 & 3.57 & 33.31 \\
T2 & 100 & 12.01 & 3.75 & 45.04 \\
T3 & 100 & 10.88 & 3.75 & 40.80 \\
T4 & 100 & 10.63 & 3.75 & 39.86 \\
T5 & 100 & 9.39 & 3.57 & 33.52 \\
T6 & 100 & 12.57 & 3.75 & 47.14 \\
T7 & 100 & 10.90 & 3.75 & 40.88 \\
T8 & 100 & 11.13 & 3.33 & 37.06 \\
T9 & 100 & 17.33 & 3.75 & 65.00 \\
T10 & 100 & 17.40 & 3.75 & 65.25
\end{tabular}

Where: Peak Value $(\boldsymbol{P V})=$ Cumulative percentage of total seed germination divided by number of days; Mean Daily Germination (MDG) $=$ Cumulative percentage of total seed germination divided by peak value; Germination Value $(\boldsymbol{G V})=$ Mean Daily Germination multiplied by Peak Value

Table 3: Analysis of Variance (ANOVA) for the germination of Faidherbia albida under different pre-treatment

\begin{tabular}{llllll}
\hline SV & DF & SS & MS & Fcal & Ftab \\
\hline Treatment & 9 & 0.59 & 0.058 & 1.72 & $1.83^{\text {ns }}$ \\
Error & 154 & 5.19 & 0.034 & & \\
Total & 163 & 5.78 & & & \\
\hline
\end{tabular}

IROKO, OA; SOWUNMI, IL; AJEKIIGBE, JM; RUFIAI, SO; WAHAB, WT 
$n s-$ Not significant $(p>0.05)$

Seed morphology, anatomy and environmental factors affect effective and sustainable germination of seeds which invariably helps to ensure successful plant propagation (Orwa et al., 2009). This study revealed that all the pre-sowing treatments gave $100 \%$ germination which is in contrast to the findings of Chuyong and Acidri (2015) who reported germination percentage in all the pre-sowing treatments applied on F. albidawere lower than $100 \%$. In this study, there was no significant difference in the treatments applied on the $F$. albida seeds. This is not in correlation to the findings of Chuyong and Acidri (2015) who reported significant difference in the treatments applied to treatments applied to the seeds of F. albida. The $100 \%$ germination in all the treatments shows that the seeds of $F$. albida have high germination potential. The result obtained for this study on the germination value shows that the seeds soaked in Conc. $\mathrm{H}_{2} \mathrm{SO}_{4}$ for 15 minutes gave the best in terms of germination value. This might be due to the fast wearing off of the seed coat which allowed quick penetration of water into the seeds. Aliero (2004) stated the importance of sulphuric acid pre-treatment in the germination of Parkia biglobosa seeds. The seeds of $F$. albida used for this study were freshly harvested and immediately subjected to the different pre-treatments.

Conclusion: This study revealed that mechanical scarification can help to increase the germination value of $F$. albida seeds. Therefore, in order to enhance optimum and uniform germination as well as, seedling production, soaking of $F$. albida seeds in concentrated $\mathrm{H}_{2} \mathrm{SO}_{4}$ for $15 \mathrm{~min}$ is recommended. Germination of this species definitely facilitates the availability of seedlings for reforestation and agroforestry programs on sustainable basis in Nigeria.

\section{REFERENCE}

Alderete-Chavez A. N., Cruz-Landero de la., GuerraSantos J.J., Guevara E., Gelabert R. (2011). Promotion of Germination of Bauhinia divaricata $L$. Seeds by Effects of Chemical Scarification. Res. J. Seed Sci. 4(1): 51-57

Aliero, B.L. (2004). Effects of Sulphuric Acid, Mechanical Scarification and Wet Heat Treatments on Germination of Seeds of African Locust Bean Tree, Parkia biglobosa. Afr. J. Biotechn. 3 (3). 179181

Alves M. C. S., Medeiros F.S., Neto M.A., Teofilo E.M. (2000). Overcoming Dormancy of Bauhna monandra and Bauhinia ungulate Seeds. Revista Brasileira Sementes 22:139-144
Amstrong W.P. (2015). Unforgettable Acacias, A Large Genus of Tress and Shrub. Wikipedia Specie Information: Faidherbia albida. https://en.m.wikipedia.org/wiki/Faidherbia

Asiedu J.B.K., Asare-Bediako E., Taah K.J., Buah J.N. (2011). Effect of Pre-Sowing Treatments on Seed Germination and Establishment of Bauhinia rufescens. International Journal of Agricultural Research. 6:584-592

Auld D.L., Bettis B.L., Crock J.E., Kephart D. (1988). Planting Data and Temperature Effects on Germination and Seed Yield of Chickpea. Agronomic J. 80 (6):909-914

Bayala j., Larwanou M., Kalinganire A., Mowo J.G., Weldeseayat S. G., Ajayi O. C., Akinnifesi F. K., Garrity D.P. (2010). Evergreen Agriculture: A Robust Approach to Sustainable Food Security in Africa. Food security 2(3): 197-214

Becking D. (2020). Faidherbia albida. Tree SA Retrieved 24 December 2020. Available @treesa.org

Bolanle-Ojo, O.T., Akinyele, A.O. and Aduradola, A.M. 2018. Morphological and Physiological Response of Artocarpus heterophyllusLam. (Jackfruit) Seedlings to Selected Environmental Factors. J. Agric. Sci. Food Res. 9: 1-7

Braam VanWyk and Piet van Wyk (1997). Field Guide to Trees of Southern Africa. Struik Nature. Pp500 ISBN 1-86825-922-6

Burrow J. E., Burrow S.M., Lotter M.C., Schmidt E. (2018). Tree and Shrub of Mozambique. Publishing Print Matters (PTY) Ltd, Noordhoek. Cape Town

Butola J.S. and Bedola H.K. (2004). Effect of PreSowing Treatment on Seed Germination and Seedling Vigour in Angelica glauca, A Threatened Medicinal Plant. Cur. Sci. 87: 796-799

Chuyong, G. B. and Acidri, T. (2015). Combining Presowing Treatments in Faidherbia albida (Delile) A. Chev. does not Imply Better Germination Success. Inter. J. Plant. Soil Sci. 8(1): 1-6

Connor K.F. (2008). Bauhinia L In: The Woody Plant Seed Manual. Boonner F.T. and Karrfalt R.P. (Eds) US Department of Agriculture, Washington DC. Pp: 295-297 
Connor K.F. (2009). Bauhinia L In: The Woody Plant Seed Manual. Boonner F.T. and Karrfalt R.P. (Eds) US Department Of Agriculture, Forest Services Washington DC Pp: 1223

Felker (1981). Uses of Trees Legumes in Semiarid Region. Economic Botany.35 (2) 174-186

FRIN 2017. Forestry Research Institute of Nigeria, Annual Meteorological Report.

Ghadiri H. and Torshiz N.B. (2000). Effect of Scarification and Temperature on Germination of Licorice (Glycyrrhiza glabra L) Seeds. J. Agric. Sci. Tech. 2(4): 257-262

Hartmann H.T., Kester D.E., Davies F.T., Geneve R.L. (1997). Plant Propagation: Principle and Practices. $6^{\text {th }}$ Edition, Prentice hall of India, New Delhi, Pp: 187-188

Idu M ., Oohinmin A.C., Onyibe H.I. (2007). Determination of Phenology, Seed Germination and Development of Hura crepitans Using Chemical Scarification. Inter. J. Botany. 3(1): 118-121

Islam A.K.M.A., Anuar N., Yaakob Z. (2009). Effect of Genotype and Pre-Sowing Treatment on Seed Germination Behavior of Jatropha. Asian J. Plant Sci.8: 433-439

Ismail M. A., Mohamed A E., Marghany R.M., AbdelMotaal F.F., Abdel-Farid, I. B., El-Sayed M. A.(2016). Preliminary Phytochemical Screening, Plant Growth inhibition and Antimicrobial Activity Studies of Faidherbia albida Legume Extracts. J. Saudi Soc. Agric. Sci. 15 112-117
Kelvin M. D. (1990). Fruit Production by Acacia albida Tree in Zambezi Riverine Woodland. J. Trop. Ecol. 6(4): 445-457

Maab Osman A. O. and Mona Abdelmoneim M. A. (2019). Phytochemical Screening and Some Biological Activities of Faidherbia albida Roots. Inter. J. Innov. Pharm. Sci. Res. 7 (5), 1-7

Maclean Ruth (2018). The Great African Regreening: Million of Magical New Trees Bring Renewal. The Guardian. Available @https://wwwtheguardian.co

Orwa C., Muta A.,Kindt R., Jamnadass R., Anthony S. (2009). Faidherbia albida: An Agroforestry Database. A Tree Reference and Selection Guide Version $\quad 4.0 \quad$ Available @ https://www.worldagroforestry. org/site/ treedbs/ treedatabase.asp/ Faidherbia_albida.pdf

Schmidt L. (2000). Guide to Handling of Tropical and Subtropical Forest Seeds. Danida Forest Seed Centre, Denmark. Pp 511 ISBN-13:9788798242864

Viswanath S., Singh R.P., Thapliyal R.C. (2002). Seed Germination Patterns in Himalayan Moist Temperate Forest. Trop. Ecol. 43(2):265-273

Willian R.L. (1993). A Guide to Forest Seed Handling: FAO Forestry Paper No 20/2 F AOrome. www.fao.org/../AF23E02.htm

Willian R.L. (1987). A Guide to Forest Seed Handling: With Special Reference to the Tropical Food And Agriculture Organization of the United Nation America. 